\title{
PENGEMBANGAN INSTRUMEN PENILAIAN KINERJA DOSEN DI PERGURUAN TINGGI
}

\author{
Yusrizal \\ Universitas Syiah Kuala Nangro Aceh Darussalam \\ Email: yusrizal63@gmail.com
}

\begin{abstract}
This study report the process of developing an assessment instrument for lecturers's performance at college. The results indicated that at the first try out, seven factors are extracted from the data obtained by using exploratory method Principal Components Analysis (PCA), which is in accordance with the theoretical estimated factors. The Confirmatory method used is Maximum Likelihood (ML) to test the goodness of fit of the 7 factors. The index of test of the seven factors is 952.062. The second try out, also found seven factors, with the index of goodness of fit of 664.287
\end{abstract}

Keywords: Construct validity, Factor analysis, The instrument for lecturer's performance

\begin{abstract}
Abstrak
Penelitian ini memaparkan proses pengembangan instrumen penilaian kinerja dosen di perguruan tinggi. Hasil penelitian menunjukkan bahwa pada ujicoba pertama, tujuh faktor yang diambil dari data yang diperoleh dengan menggunakan metode eksplorasi Principal Components Analysis (PCA), yang sesuai dengan faktor perkiraan teoritis. Metode Konfirmatori yang digunakan adalah Maximum Likelihood (ML) untuk menguji kecocokan dari 7 faktor. Indeks dari uji tujuh faktor adalah 952,062. Uji coba kedua juga memperoleh tujuh faktor, dengan indeks kecocokan 664,287.
\end{abstract}

Kata kunci: Bina validitas analisis faktor, Instrumen untuk kinerja dosen, penilaian

\section{PENDAhUluan}

Undang-Undang Nomor 21 Tahun 2003 Tentang Sistem Pendidikan Nasional menyebutkan bahwa penyelenggaraan pendidikan tinggi bertujuan untuk menyiapkan generasi bangsa agar mempunyai kualitas akademik dan intelektual yang baik sehingga dapat menguasai ilmu pengetahuan dan teknologi, serta menyiapkan calon-calon pemimpin masa depan yang berwawasan luas dan mampu menjawab tantangan bangsa dalam persaingan global yang semakin tajam (Diknas, 2003:45).

Untuk mencapai tujuan pendidikan tinggi tersebut dan menghasilkan sumber daya manusia yang berkualitas dan mampu bersaing dalam era global hanya dapat dilakukan oleh perguruan tinggi yang bermtu. Salah satu faktor penting yang mempengaruhi mutu pendidikan tinggi adalah dosen, karena dosen merupakan ujung tombak terdepan yang secara langsung berhadapan dengan mahasiswa pada bidang atau keahliannya masing-masing.

Menurut Djamas (2005:17) masalah dosen merupakan kunci dari segala usaha untuk meningkakan kualitas perguruan tinggi. Segala usaha untuk meningkatkan mutu pendidikan tinggi tanpa meningkatkan mutu dosennya merupakan usaha yang sia-sia. Karena itu, sebagai tenaga pengajar, dosen merupakan salah satu faktor penentu keberhasilan pendidikan tinggi. Ini bermakna bahwa kualitas kinerja perguruan tinggi sangat 
ditentukan oleh kualitas kinerja kolektif sivitas akademika, termasuk di dalamnya dosen.

Suryabrata (2004:1) mengemukakan bahwa perguruan tinggi di Indonesia me-ngemban tiga dharma atau tugas, yaitu (a) tugas pendidikan dan pengajaran, (b) tugas penelitian, dan (c) tugas pengabdian kepada masyarakat. Ini berarti pula bahwa dosen sebagai unsur utama dalam kegiatan akademik di kampus harus mengemban ketiga tugas itu sekaligus. Jadi dosen yang bertugas di perguruan tinggi harus (1) mempunyai wawasan yang luas dalam tugas melaksanakan pendidikan dan pengajaran untuk menghasilkan manusia-manusia terdidik, (2) mampu melaksanakan penelitian sesuai bidangnya masing-masing untuk menemukan kebenaran dalam ilmu pengetahuan, dan (3) dapat melaksanakan pengabdian kepada masyarakat yang merupakan kegiatan memanfaatkan ilmu pengetahuan untuk kemajuan/kesejahteraan masyarakat.

Dalam pelaksanaan dharma pendidikan dan pengajaran, bagi sebagian besar dosen kegiatan pengajaran sudah menjadi kegiatan rutin. Dimulai dari diterimanya surat penugasan mengajar berikut jadwal dan waktu kuliah, kemudian dilanjutkan mengikuti arahan dari ketua jurusan atau ketua program studinya. Menurut Utomo dan Kees Ruijter (1985:28) dosen dalam memberi kuliah harus memikirkan pengaturan pemilihan bahan yang representatif, dan aktualitas agar bermanfaat untuk masa depan mahasiswa. Terkait dengan hal itu, pada umumnya para dosen sudah menyusun rancangan perkuliahan atau menyiapkan materi kuliah baik berupa hand out atau berupa diktat atau dalam bentuk yang lainnya sebelum kuliah dimulai. Ada juga dosen yang menyiapkan bahan perkuliahannya dengan cara memperbaharui materi perkuliahan tahuntahun sebelumnya. Tetapi menurut Danim (2003:208) banyak juga dosen yang sama sekali tidak menulis diktat, modul, dan naskah tutorial sebagai bahan perkuliahan.

Metode pengajaran sangat erat kaitannya dengan kemampuan dosen dalam bertindak sebagai manajer di kelas, motivator mahasiswa, sebagai pengayom dan sebagainya (Soekartawi dkk, 1995:10). Banyak dosen dalam mengajar sudah menggunakan metode mengajar yang bervariasi atau sesuai bahan ajarnya. Namun, menurut Soekartawi, dkk (1995:33) ada dosen setelah menerima surat tugas dimulailah kegiatan mengajar yang umumnya dilakukan dengan cara ceramah secara rutin setiap minggu, memberikan kuis, tes, dan ujian, memasukkan nilai ujian.

Dari uraian di atas terlihat sangat beragam kegiatan dosen dalam melaksanakan tugas profesionalnya dalam bidang pendidikan dan pengajaran. Ini artinya kinerja dosen dalam melaksanakan tugas Tri Dharma Perguruan Tinggi khususnya dalam bidang pendidikan dan pengajaran sangat bervariasi antara dosen yang satu dengan dosen yang lainnya, atau dosen pada satu perguruan tinggi dengan dosen pada perguruan tinggi lainnya. Kita tidak dapat menentukan tinggi rendahnya capaian kinerja seseorang dosen yang variatif tersebut karena sampai saat ini belum ada suatu alat ukur untuk tujuan itu.

Sekarang ini, prestasi/kinerja dosen hanya dinilai secara umum berdasar isian DP3. Oleh karena DP3 tidak mempunyai parameter-parameter yang jelas sehingga diperlukan alat penilaian lain yang baku dan dapat digunakan.

Berkaitan dengan uraian di atas, dipandang penting dan perlu mengembangkan suatu instrumen yang objektif, valid dan reliabel yang dapat digunakan untuk menilai kinerja dosen dalam melaksanakan dharma pendidikan dan pengajaran.

Berdasarkan uraian di atas, maka dapat dirumuskan permasalahan sebagai verikut: (1) Bagaimanakah menyusun dan mengembangkan instrumen penilaian kinerja dosen di perguruan tinggi? (2) Indikator-indi- 
kator apa sajakah yang mendasari instrumen penilaian kinerja dosen di perguruan tinggi? (3) Bagaimanakah validitas konstruk instrumen penilaian kinerja dosen yang dikembangkan? (4) Bagaimanakah reliabilitas instrumen penilaian kinerja dosen yang dikembangkan?

\section{A. Hakikat Kinerja}

Whitmore (1997:104) mengemukakan pengertian kinerja sebagai suatu perbuatan, suatu prestasi atau apa yang diperlihatkan seseorang melalui keterampilannya yang nyata. Lase (2003:31) mengemukakan definisi konseptual kinerja sebagai penilaian seseorang tentang potensi dan tingkat pemenuhan kerja yang terdiri dari perbuatan, prestasi, keterampilan di depan umum, kompetensi, dan juga tuntutan mengemban tanggungjawab.

Baik buruknya kinerja tidak hanya dilihat dari tingkat kuantitas yang dapat dihasilkan seseorang dalam bekerja, akan tetapi juga diukur dari segi kualitasnya. Mangkunegara (1995: 45) mengatakan bahwa kinerja adalah hasil kerja secara kualitas dan kuantitas yang dicapai oleh seseorang dalam melaksanakan tugasnya sesuai dengan tanggungjawab yang diberikan kepadanya. Hal senada juga dikemukakan oleh Schermerhorn (1999:309) yaitu kinerja adalah kuantitas dan kualitas prestasi tugas dari seseorang atau kelompok. Definisi ini menunjukkan bahwa ada ukuran-ukuran tertentu untuk mengetahui derajat kinerja seseorang baik dalam bentuk jumlah hasil pekerjaan atau kuantitas dan mutu atau kualitas pekerjaan.

Banyak batasan lain yang diberikan para pakar tentang istilah kinerja. Semuanya mempunyai visi yang agak berbeda, tetapi secara prinsip mereka setuju bahwa kinerja mengarah pada suatu upaya dalam rangka mencapai prestasi kerja yang lebih baik. Maier sebagai-mana yang dikutip oleh As'ad (1997:46) misalnya, menyatakan bahwa kinerja merupakan kesuksesan seseorang dalam melaksanakan suatu pekerjaan. Pengertian ini menjelaskan bahwa kinerja adalah hasil yang dicapai oleh seseorang menurut ukuran yang berlaku untuk pekerjaan yang bersangkutan.

Kinerja yang baik akan dipengaruhi oleh dua hal yaitu tingkat kemampuan dan motivasi kerja yang baik (Mitchell, 1982: 159). Kemampuan seseorang dipengaruhi oleh pemahamannya atas jenis pekerjaan dan keterampilan melakukannya, oleh karenanya seseorang harus dapat meningkatkan kemampuan dan keterampilannya. Selain itu konstribusi motivasi kerja terhadap kinerja tidaklah dapat diabaikan. Meskipun kemampuan karyawan sangat baik apabila motivasi kerjanya rendah, sudah barang tentu kinerjanya juga akan rendah. Seirama dengan hal ini, Prawirosentono (1999:193) menyatakan bahwa untuk menilai kinerja perse-orangan adalah melalui persamaan: kinerja=kemampuan (kapasitas) + motivasi

Berdasarkan deskripsi teori-teori di atas, maka kinerja dapat disimpulkan sebagai kombinasi dari faktor-faktor motivasi dengan upaya, kemampuan, ketrampilan dan juga tuntutan dalam mengemban tanggung-jawab.

\section{B. Tugas Dosen}

Dalam Undang-Undang No. 20 Tahun 2003 Tentang Sistem Pendidikan Nasional disebutkan bahwa pendidik yang mengajar pada satuan pendidikan tinggi disebut dosen, berarti dosen adalah tenaga pendidik dan pengajar di perguruan tinggi. Karena itu. dosen sebagai unsur pengajar pada lembaga pendidikan tinggi dengan sendirinya mempunyai fungsi menunjang sekaligus mewujudkan tercapainya tujuan pendidikan tinggi, yaitu melaksana-kan pendidikan dan pengajaran, penelitian dan pengabdian kepada masyarakat

Tugas atau kegiatan pendidikan dan pengajaran, penelitian dan pengabdian kepada masyarakat adalah tugas profesional yang tidak dapat dilaksanakan oleh sembarang orang, sebab yang dihadapi adalah mahasiswa yang nantinya diharapkan menjadi pemimpin 
di berbagai bidang, baik bidang pekerjaan maupun ilmu pengetahuan pada lembaga keilmuan.

Menurut Sudjana (1995: 15), pekerjaan yang bersifat profesional adalah pekerjaan yang hanya dapat dilakukan oleh mereka yang secara khusus disiapkan untuk itu dan bukan pekerjaan yang dilakukan oleh mereka yang tidak dapat atau tiidak memperoleh pekerjaan lain. Walaupun tugas dosen memang tidak $100 \%$ waktunya untuk mengajar, namun pekerjaan mengajar adalah pekerjan utama dan perlu dilaksanakan secara profesional. Karena profesi inilah maka pekerjaan mengajar tidak boleh dilaksanakan dengan setengah hati atau tidak serius. Colletti sebagaimana dikutip Soekartawi, dkk (1995: 123) mengemukakan bahwa pekerjaan dosen adalah pekerjaan profesi yang perlu dilaksanakan secara profesional.

Dari uraian tersebut, dapatlah ditegaskan bahwa seorang dosen dikatakan profesional apabila memiliki keahlian dalam bidangnya, bertanggung jawab, dan memiliki rasa kesejawatan. Di samping itu, sebagai profesional, dosen haruslah selalu meningkatkan pengetahuan, sikap, dan keterampilannya secara terus menerus, sesuai tuntutan tugasnya.

\section{Penilaian Kinerja Dosen}

Dikaitkan dengan konsep Dunkin dan Biddle dalam Reddy (1998:122), yang mengemukakan bahwa dalam menilai kinerja dosen variabel proses lebih penting dari pada variabel hasil, maka penilaian kinerja dosen bidang pendidikan dan pengajaran merujuk pada capaian-capaian dosen dalam mengajar dan atau melatih, mulai dari merencanakan, mempersiapkan dan melaksanakan pengajaran di dalam kelas.

Suryabrata (2004:1) mengemukakan bahwa perguruan tinggi di Indonesia mengemban Tri Dharma atau tugas, yaitu (a) tugas pendidikan dan pengajaran, (b) tugas penelitian, dan (c) tugas pengabdian kepada masya- rakat. Dalam Surat Keputusan (SK) Menteri Negara Koordinator Bidang Pengawasan Pembangunan dan Pendayagunaan Aparatur Negara, Nomor 38 tentang Jabatan Fungsional Dosen dan Angka Kreditnya, pasal 4 disebutkan bahwa rincian tugas dosen, meliputi dua belas macam tugas dosen dalam bidang pendidikan dan pengajaran, lima macam dalam bidang penelitian, dan lima macam dalam bidang pengabdian kepada masyarakat. Karena itu tenaga pengajar sebagai unsur utama dalam kegiatan akademik di kampus, juga harus mengemban ketiga tugas itu sekaligus.

Bila uraian di atas dikaitkan dengan kinerja, maka dapat disimpulkan bahwa yang dimaksud dengan kinerja dosen di perguruan tinggi adalah capaian yang disyaratkan oleh tugas dalam menjalankan tanggungjawab profesionalnya dalam pelaksanaan, penyelenggaraan kewajiban atau tugas seorang dosen yang dicerminkan melalui kegiatan dari 3 (tiga) bidang tersebut, yaitu (1) bidang pendidikan dan pengajaran, (2) bidang penelitian, (3) bidang pengabdian kepada masyarakat

Penilaian paling mendasar terhadap dosen dalam bidang pendidikan dan pengajaran adalah yang berkaitan dengan capaian dalam tugas mengajar, mulai dari saat dosen membuat persiapan hingga pelaksanaan evaluasi. Penilaian capain kegiatan-kegiatan selama proses pengajaran tersebut dinamakan penilaian kinerja dosen, karena pada dasarnya kinerja merupakan capaian yang disyaratkan oleh tugas

Untuk mengetahui kinerja dosen bidang pendidikan dan pengajaran perlu diadakan penilaian. Salah satu pihak yang dapat melakukan penilaian terhadap kinerja dosen adalah mahasiswa. Mahasiswa dapat menilai pengajaran dosennya secara adil dan secara perspektif. Jadi, bila mahasiswa yang menilai dosennya akan lebih objektif jika dibandingkan bila yang menilai itu adalah atasannya. 
Shackelford dan Henak dalam Soekartawi (1995:37-38) memberikan sepuluh kriteria dalam dalam upaya mendefinisikan ciriciri pengajar (dosen) yang efektif, yaitu (a) mempunyai intusiastik, (b) mempunyai keterampilan berkomunikasi, (c) dapat menjelaskan persoalan atau topik secara jelas, (d) menguasai bahan ajar, (e) mampu membuat suasana kelas menjadi hidup, (f) fleksibel, (g) memberikan bahan ajar terorganisasi secara rapi sesuai dengan silabus, (h) adil dalam memberi nilai, (i) mau menerima umpan balik, dan (j) akrab dengan situasi kelas. Riyanto (2003:47) mengemu kakan komponen-komponen mengajar di perguruan tinggi adalah meliputi (1) tujuan, (2) bahan, (3) metode, (4) dosen, (5) mahasiswa, (6) fasilitas, (7) interaksi, dan (8) evaluasi.

Berdasarkan uraian di atas dapat dikemukakan definisi konseptual dari kinerja dosen bidang pendidikan dan pengajaran yaitu capaian yang diperoleh dosen dalam melaksanakan tugas profesionalnya sebagai pengajar yang meliputi antara lain: perencanaan perkuliahan, pelaksanaan kegiatan pembelajaran, penguasaan materi, pengelolaan kelas, kemampuan berkomunikasi dengan mahasiswa, kedisiplinan, dan melakukan penilaian terhadap hasil belajar mahasiswa.

\section{Validitas Konstruk}

Menurut Suryabrata (2000:42) validitas konstruk (construct validity) mempersoalkan sejauhmana skor-skor hasil pengukuran dengan suatu instrumen merefleksikan konstruk teoritik yang mendasari penyusunan alat ukur tersebut. Validitas konstruk menunjuk pada sejauh mana suatu instrumen mampu mengukur pengertian-pengertian yang terkandung dalam materi yang akan diukur (Hamzah B.Uno,dkk, 2001:140)

Untuk mengukur kinerja perlu didefinisikan terlebih dahulu apa itu kinerja. Untuk melahirkan definisi kinerja diperlukan sejumlah teori. Menurut Hadi (1986:113) jika bangunan teorinya sudah benar, maka hasil pengukuran yang menggunakan alat pengukur yang berbasis pada teori itu dipandang valid.

Menurut Suryabrata (2002:42) ada dua metode yang telah diakui oleh para ahli di bidang ini yakni (1) analisis faktor, dan (2) sifat jamak-metode-metode jamak (multitraitmultimethod analysis). Pengertian konstruk yang bersifat terpendam dan abstrak, biasanya berkaitan dengan banyak indikator perilaku empirik, menuntut adanya uji analisis melalui analisis faktor. Analisis faktor dapat digunakan untuk menguji hipotesis-hipotesis mengenai eksistensi konstruk-konstruk, atau untuk mencari konstruk-konstruk dalam kelompok variabel-variabel. Menurut Ancok (2002: 21) bila alat pengukur telah memiliki validitas konstruk berarti semua item (pertanyaan atau pernyataan) yang ada di dalam alat pengukur itu mengukur konsep yang ingin diukur

Suyanto (1988: 234) mengemukkan bahwa analisis faktor merupakan kajian tentang kesalingtergantungan antara variabelvariabel, dengan tujuan untuk menemukan himpunan variabel-variabel baru yang lebih sedikit jumlahnya daripada jumlah variabel semula dan yang menunjukkan mana di antara variabel-variabel semula itu merupakan faktor-faktor persekutuan.

\section{METODOLOGI PENELITIAN}

\section{A. Tahap-Tahap Pengembangan Instrumen}

Tahap-tahap pengembangan instrumen penilaian kinerja dosen di perguruan tinggi dapat diuraikan sebagai berikut:

Pertama, pengembagan definisi konseptual dan operasional dari variabel kinerja dosen sebagai suatu respons psikologis dalam bentuk perasaan atau emosi seseorang dengan tujuh komponen sebagaimana diuraikan di atas.

Kedua, penyusunan butir-butir kinerja dosen di perguruan tinggi sebagai instrumen penilaian berdasarkan skala diferensial semantik dilanjutkan konfirmasi keterbacaan 
butir-butir instrumen kepada promotor (diperoleh draf 1).

Ketiga, ujicoba kepada kelompok panelis ahli sebagai judges untuk seleksi butirbutir berdasarkan median (Md) dan nilai rentangan interquartil $(\mathrm{Q})$ karena menggunakan skala Thrustone dilanjutkan dengan revisi draf 1, dan diperoleh draf 2 .

Keempat, ujicoba 1 ke mahasiswa FKIP Unsyiah dilanjutkan penentuan validitas konstruk dengan menggunakan analisis faktor dan reliabilitas konsistensi internal alpha, diperoleh draf 3

Kelima, ujicoba 2 ke mahasiswa FKIP Unsyiah dilanjutkan penentuan validitas konstruk dengan menggunakan analisis faktor dan reliabilitas konsistensi internal alpha serta ditetapkan norma atau panduan penggunaan instrumen penilaian kinerja dosen di perguruan tinggi, Akhirnya diperoleh instrumen penilaian kinerja dosen yang objektif, valid dan reliabel.

\section{B. Definisi Kawasan yang Diukur}

Definisi operasional dan kisi-kisi pengembangan instrumen penilaian kinerja dosen di perguruan tinggi diuraikan sebagai berikut:

Kinerja dosen bidang pendidikan dan pengajaran adalah ukuran satuan kinerja yang dinyatakan dalam skor yang diperoleh dosen atas pelaksanaan tugas profesinya sebagai pengajar yang ditunjukkan melalui kegiatan antara lain perencanaan perkuliahan, pelaksanaan kegiatan pembelajaran, penguasan materi, pengelolaan kelas, kemampuan berkomunikas dengan mahasiswa, kedisiplinan, dan melakukan penilaian terhadap hasil belajar mahasiswa, yang diukur berdasarkan penilaian oleh mahasiswa.

\section{Kisi-Kisi Instrumen}

Di dalam pengembangan instrumen penilaian kinerja dosen bidang pendidikan dan pengajaran ini, pertama-tama dibuat spesifikasi rancangan penyusunan instrumen penilaian kinerja dosen di perguruan tinggi

Setiap butir pernyataan dalam instrumen menyatakan suatu keadaan situasi atau perasaan yang dirasakan mahasiswa. Butirbutir pernyataan tersebut disertai dengan tujuh pilihan jawaban dari sangat positif sampai sangat tidak positif. Di dalam penelitian ini dikembangkan sebanyak 118 butir pernyataan dengan menggunakan skor kontinum dari 1 sampai 7

\section{Hasil Pengembangan Instrumen Pemilihan Butir-Butir Pernyataan}

Di dalam ujicoba ini diambil judges sebanyak 55 orang ahli di bidang evaluasi pendidikan dan pengembangan instrumen. Mereka diminta memberikan bobot kepada setiap pernyataan menurut suatu kontinun psikologis. Caranya, setelah rancangan instrumen selesai maka dimintakan pendapat para ahli yang kompeten dengan topik tersebut dan dilanjutkan dengan menghitung nilai median $(\mathrm{Md})$ dan rentangan interkuartil (Q) karena instrumen memakai kontinum skala Thrustone. Sasaran penilaian mencakup adanya kesesuaian penjabaran konstruk yang digunakan menjadi butir-butir pernyataan.

Dari hasil penilaian pakar disimpulkan perolehan butir sebanyak 71 butir dan selanjutnya disusun instrumen baru (draf 2) dengan perincian seperti terlihat pada tabel 2 di bawah disertai dengan perubahan dari nomor lama ke nomor baru. Indikatorindikator (1) perencanaan perkuliahan ada 5 butir, (2) pelaksanaan kegiatan pembe lajaran ada 14 butir, (3) penguasaan materi ada 8 butir, (4) pengeloaan kelas ada 20 butir, (5) kemampuan berkomunikasi dengan mahasiswa ada 12 butir, (6) kedisiplinan ada 7 butir, dan (7) evaluasi hasil bealjar mahasiswa ada 7 butir.

\section{E. Penentuan Validitas Konstruk 1) Uji coba pertama}


Pada pelaksanaan uji coba pertama instrumen yang digunakan adalah instrumen penilaian kinerja dosen (draf 2) dan diuji cobakan kepada 510 orang mahasiswa FKIP Universitas Syiah Kuala Darussalam Banda Aceh. Validitas konstruk dianalisis dengan menggunakan analisis faktor. Komputasi data uji coba pertama, menunjukkan Kaiser Meyer Olkin mengenai measure of sampling adequacy (KMO MSA) sebesar 0,913 dengan signifikansi sebesar 0,000. Angka 0,913 berada di atas 0,5 dan signifikansi 0,000 lebih kecil dari 0,05, jadi adalah baik menurut kriteria Norusis (1993).

Dari uji Bartleet untuk test of sphericity diperoleh Chi Square sebesar 14362.65 dengan derajat kebebasan 2485 dengan signifikan pada 0,000, yang berarti matriks korelasi bukan merupakan matrik identitas sehingga dapat digunakan analisis faktor. Pada tabel anti image correlation (AIC) ditemukan harga MSA di bawah 0,50 ,yaitu pada butir-butir nomor 1 , nomor 27 , nomor 35 , dan butir nomor 70 sehingga untuk proses selanjutnya keempat butir ini tidak diikutsertakan.

Ekstraksi dengan menggunakan metode PCA (Principal Component Analysis), diperoleh bilangan pada tabel communalities untuk butir 1 sebesar 0,661. Ini bermakna variansi dari butir atau variabel 1 dapat dijelaskan oleh faktor yang terbentuk.

Pada tabel total variance explained ada 71 butir yang dimasukkan ke dalam analisis faktor didapatkan nilai akar karakteristik (eigen values) di atas $1(\geq 1)$ ada sebanyak 16 faktor, lebih banyak dari yang diestimasikan, yaitu 7 faktor. Setelah dikeluarkan 31 butir sehingga jumlah butir yang tinggal ada sebanyak 40 butir, dan hasil analisis dari 40 butir, didapatkan nilai KMO MSA sebesar 0,933. Di samping itu nilai Bartlett's test of Sphericity sebesar 7609.987 pada derajat kebebasan 780 dengan taraf signifikansi 0,000, dengan demikian matriks korelasi yang terbentuk bukan matriks identitas.

Pada Tabel total variance explained dari 40 butir yang dimasukkan dalam analisis faktor didapatkan nilai akar karakteristik (eigen value) di atas $1(\geq 1)$ ada sebanyak 7 faktor, sesuai dengan banyaknya indikator yang diestimasikan

Dengan demikian dapat disimpulkan bahwa instrumen penilaian kinerja dosen tersebut adalah valid ditnjau dari validitas konstruk. Selain itu adanya varians muatan faktor yang dapat menjelaskan varians kinerja dosen, muatan secara kumulatif ke tujuh faktor tersebut adalah sebesar 51,769\%. varians

Selanjutnya tampilan scree plot merupakan penjelasan untuk tabel total variance explained dalam bentuk grafik. Diagram scree plot menunjukkan bagaimana kecenderungan penurunan nilai eigen (eigenvalues) yang dipakai untuk menentukan secara subjektif banyaknya faktor yang dipakai. 


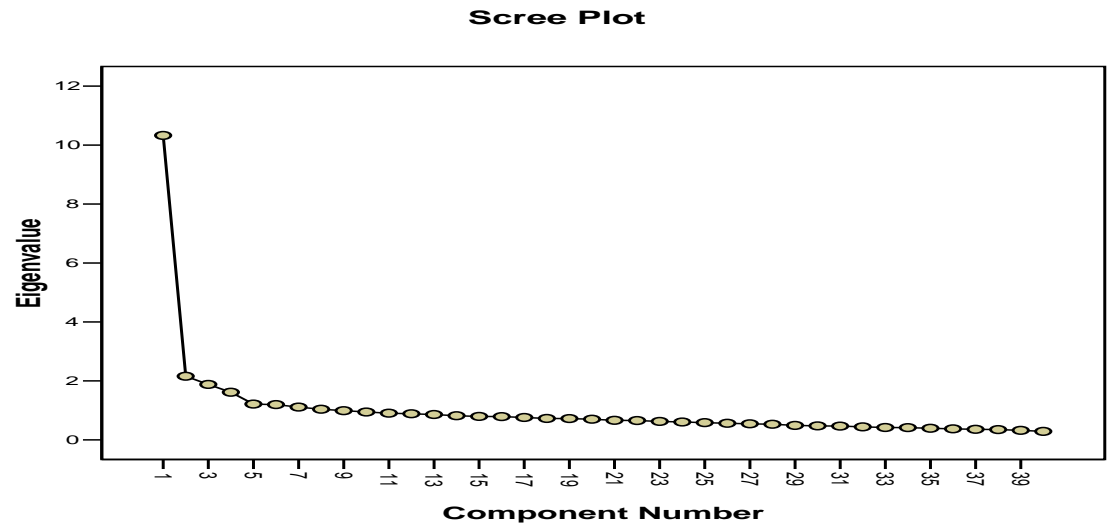

Gambar 1. Total Variance Explained

Pada rotated component matrix setelah dilakukan 24 putaran atau iterasi, menunjukkan bahwa tidak ada butir yang melewati muatan faktor "cut off point" lebih kecil dari $0,30 \quad(<0,30)$. Muatan faktor terbesar terdapat pada butir 31 sebesar 0,736 dan terkecil pada butir 20 sebesar 0,356. Dengan demikian semua butir pernyataan adalah valid.

Di sini terjadi pergeseran sejumlah butir dari faktor yang dirancang, yaitu bergabungnya butir-butir dari faktor kedisiplinan, komunikasi, dan evaluasi hasil belajar mahasiswa, sehingga sebaran butir yang dikembangkan terjdi perubahan letak. Akibatnya nama-nama faktor sedikit mengalami perubahan, namun tetap bagian dari faktor yang telah diestimasikan. Faktor yang mengalami perubahan nama adalah faktor 4 (strategi pembelajaran) dan faktor 5 (penguasaan metodelogi) yang semula merupakan faktor pengelolaan kelas. Tampilan component plot in rotated space yang merupakan hasil rotasi faktor dalam bentuk tiga dimensi diperlihatkan dalam gambar 2 di bawah.

Component Plot in Rotated Space

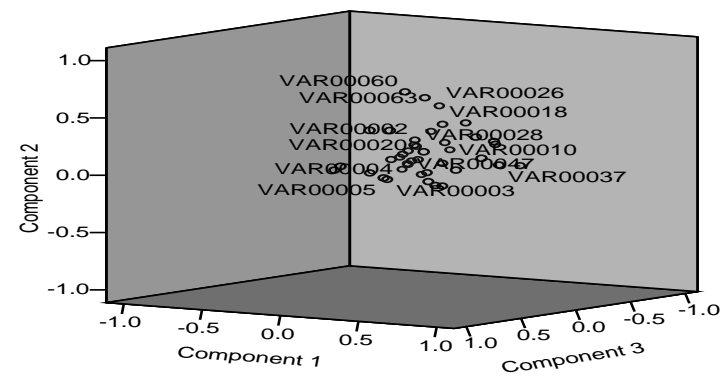

Gambar 1. Total Variance Explained 
Komputasi menggunakan pendekatan konfirmatori yang dilakukan melalui metode Maximum Likelihood (ML) untuk menguji kesesuaian goodness of fit test menghasilkan indeks sebesar 952.062 dengan derajat kebebasan 521 dan probabilitas 0,000. Dengan demikian faktor berdistribusi normal multivariat.

Dengan nilai $\chi^{2}$ hasil $=952,062>\chi^{2}$ tabel $=649.69$ dengan derajat kebebasan 521 dan taraf signifikansi di atas 0,000, maka dapat disimpulkan bahwa pada uji coba pertama ini, instrumen penilaian kinerja dosen yang dikembangkan telah memiliki validitas konstruk yang baik.

\section{2) Uji coba kedua}

Pada pelaksanaan ujicoba kedua yang digunakan adalah instrumen hasil ujicoba pertama yang mengandung 40 butir pernyataan. Selanjutnya instrumen ini disebut instrumen penilaian kinerja dosen di perguruan tinggi (draf 3) yang diuji cobakan kepada 260 mahasiswa FKIP Unsyiah.

Validitas konstruk dianalisis dengan menggunakan anlisis faktor. Hasil komputasi data ujicoba kedua diperoleh Kaiser Meyer Olkin mengenai measure of sampling adequacy (KMO MSA) sebesar 0.894 yang termasuk baik berdasarkan kriteria Norusis (1993). Uji Bartlett untuk test of sphericity diperoleh Chi Square sebesar 3854.488, pada derajat kebebasan 595 dengan signifikansi pada $0.000<0,05$, dengan demikian matriks korelasi yang terbentuk bukan matrik identitas.

Pada tabel total variance explained dari 40 butiir yang dimasukkan dalam analisis faktor didapatkan nilai akar karakteristik (eigen value) ada sebanyak 10 faktor, lebih banyak dari kajian teori, yaitu 7 faktor. Setelah dikeluarkan 9 butir sehingga jumlah butir yang tinggal ada sebanyak 31 butir, dan hasil analisis didapatkan nilai KMO MSA sebesar 0.899. Nilai ini juga termasuk dalam kategori baik. Di samping itu nilai Bartlett's test of Sphericity diperoleh sebesar 4397.690 pada derajat kebebasan 630 dengan taraf signifikan 0.000 , dengan demikian matriks korelasi yang terbentuk bukan matriks identitas, jadi analisis faktor bisa dilanjutkan. Pada Tabel total variance explained dari 31 butir yang dimasukkan dalam analisis faktor didapatkan nilai akar karakteristik (eigen value) di atas 1 ada sebanyak 7 faktor, sesuai dengan banyaknya indikator yang diestimasikan.

Dengan demikian dapat disimpul kan bahwa instrumen penilaian kinerja dosen di perguruan tinggi tersebut adalah sahih ditinjau dari kesahihan konstruk. Selain itu adanya variansi muatan faktor yang dapat menjelaskan adanya variansi penilaian kinerja dosen, muatan oleh faktor pertama $30.861 \%$, kedua $6.412 \%$, ketiga $4.803 \%$, keempat $4.007 \%$, kelima $3.730 \%$, keenam $3.388 \%$ dan ketujuh $3.130 \%$, sehingga secara kumulatif ketujuh faktor tersebut adalah sebesar $56.331 \%$ variansi.

Diagram Scree plot menunjukkan bagaimana kecendrungan penurunan nilai eigen (eigen value) yang dipakai untuk menentukan seara subjektif banyaknya faktor yang dipakai. 


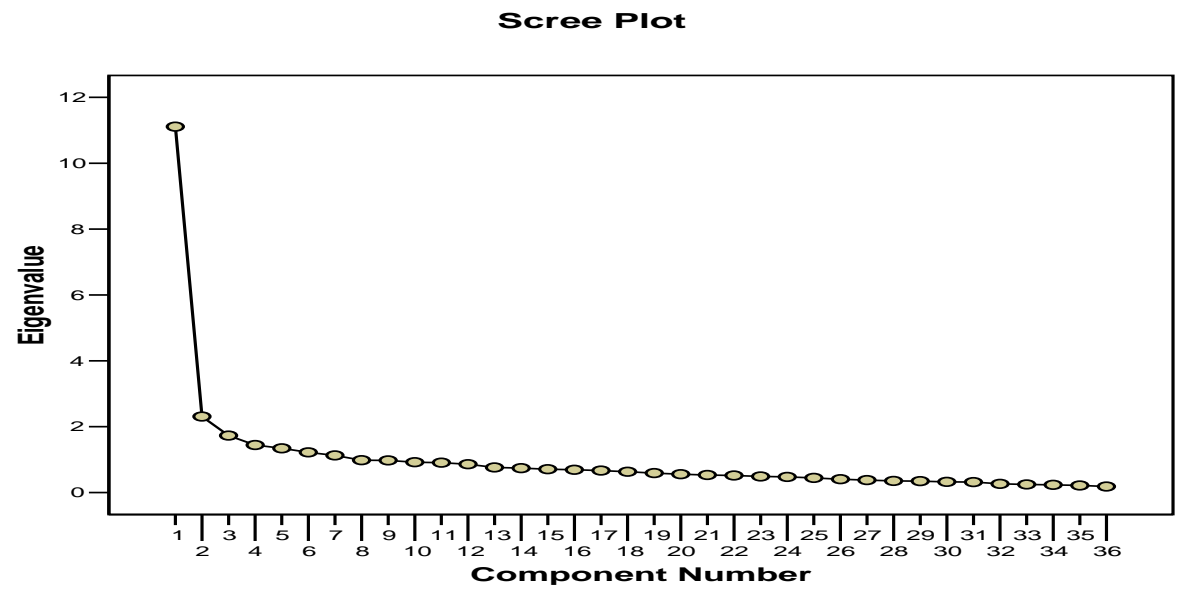

\section{Gambar 3. Scree Plot}

Tampilan component plot in rotated space merupakan hasil rotasi faktor yang diperlihatkan dalam bentuk tiga dimensi. Lihat gambar 4.

Komputasi dengan metode Maximum Likelihood (ML), untuk menguji kesesuaian goodness of fit test menghasilkan indeks sebesar 664.287 dengan derajat kebebasan 398 dan probalitas 0,000. Dengan demikian faktor berdistribusi normal.
Dengan nilai $\chi^{2}$ hasil $=664.287>\chi^{2}$ tabel $=511.57$ dengan derajat kebebasan 398 dan taraf signifikansi $0,01 \%$, maka dapat disimpulkan bahwa pad uji coba kedua ini instrumen penilaian kinerja dosen di perguruan tinggi yang dikembangkan telah memiliki validits konstruk yang baik.

\section{Component Plot in Rotated Space}

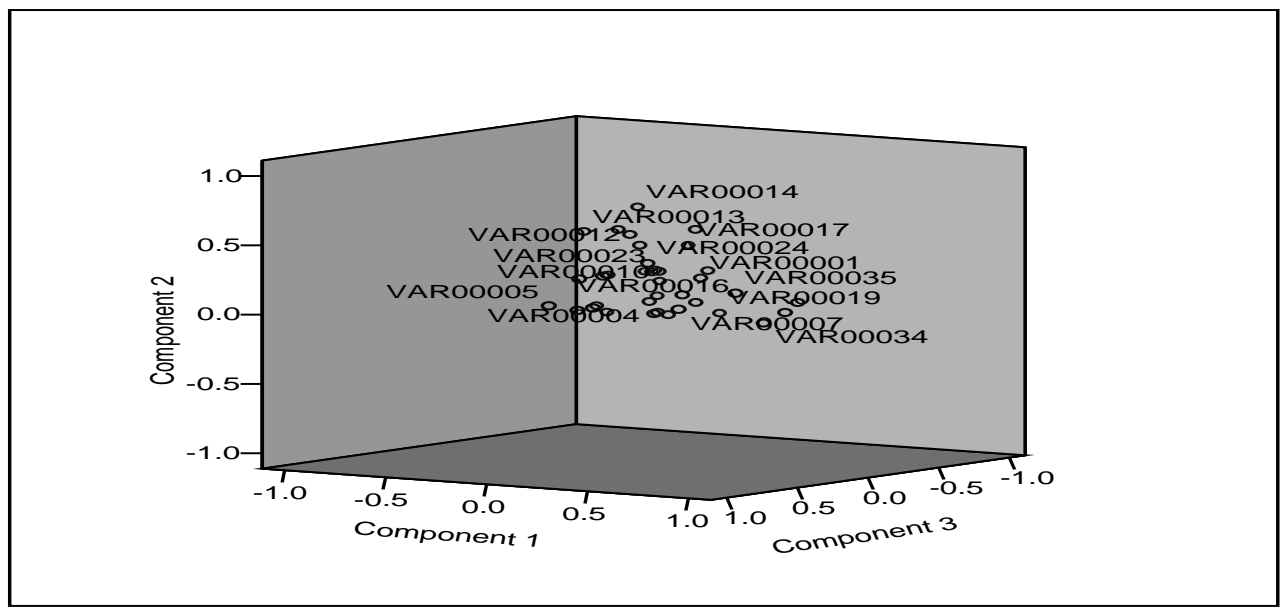

Gambar 4. Component Plot In Rotated Space Uji Coba 


\section{3) Penentuan Reliabilitas}

Reliabilitas instrumen penilaian kinerja dosen dihitung menggunakan rumus konsistensi internal alpha Cronbach. Per-

\section{HASIL DAN PEMBAHASAN}

Dari kedua uji coba dengan menggunakan analisis faktor secara konseptual hasilnya telah sesuai dengan teori yang diestimasikan 7 faktor, yaitu: (1) perencanan perkuliahan, (2) pelaksanaan kegiatan pembelajaran, (3) penguasaan materi, (4) strategi pembelajaran, (5) penguasaan metodologi, (6) pengelolaan kelas, dan (7) komunikasi dengan mahasiswa, kedisiplinan, evaluasi hasil belajar mahasiswa.

Perhitungan reliabilitas konsistensi internal instrumen, menghasilkan koefisien masing-masing sebesar 0,931 pada uji coba pertama dan 0,934 pada uji coba kedua. Dengan demikian dapat dikatakan bahwa butir-butir pernyataan di dalam instrumen hitungan dilakukan dengan bantuan program SPSS version 13,0 Windows. Dari komputasi data uji coba pertama diperoleh koefisien sebesar 0,931, dan hasil komputasi data uji coba kedua diperoleh koefisien sebesar 0,934. penilaian kinerja dosen yang dikembangkan ini memilik konsistensi internal yang cukup tinggi

Tabel 3 berikut adalah rangkuman hasil uji coba yang menggunakan analisis faktor, pendekatam eksploratori (PCA) dan pendekatan konfirmatori (ML). Metode konfirmatori menggunakan kebolehjadian maksimum (Maximum likelihood) menghasilkan kesesuaian goodness of fit test model $\chi^{2}$ yang mempunyai probabilitas yang sangat memadai disertai derajat kebebasan $\mathrm{dk}=521$ dan $\mathrm{dk}=398$ dan taraf signifikansi $\alpha=0,01$ $\%$. Selain itu, juga ditunjukkan hasil penghitungan koefisien reliabilitas instrumen.

Tabel 1. Rangkuman Hasil Analisis Faktor

\begin{tabular}{|c|c|c|c|c|c|}
\hline \multirow[b]{2}{*}{ Ujicoba } & \multicolumn{4}{|c|}{ Validitas Konstruk } & \multirow[b]{2}{*}{$\begin{array}{l}\text { Reliabilitas } \\
\qquad(\alpha)\end{array}$} \\
\hline & $\begin{array}{l}\text { Ekstraksi } \\
\text { faktor }\end{array}$ & $\begin{array}{c}(\%) \\
\text { kumulatif }\end{array}$ & $\begin{array}{c}\text { Goodness of fit } \\
\text { test }\end{array}$ & Verifikasi butir & \\
\hline $\begin{array}{l}\text { Empiris } \\
\text { I }\end{array}$ & 7 & 51.769 & $\begin{array}{l}\chi^{2}=952.062 \\
\mathrm{dk}=521 \\
\mathrm{p}=0.000\end{array}$ & $\begin{array}{l}\text { dari jumlah butir } \\
71 \text {, terpilih } 40 \text { butir }\end{array}$ & $0, \overline{-}$ \\
\hline $\begin{array}{c}\text { Empiris } \\
\text { II }\end{array}$ & 7 & 56.331 & $\begin{array}{l}\chi^{2}=664.287 \\
d k=398 \\
p=0.000\end{array}$ & $\begin{array}{l}\text { dari jumlah butir } \\
40 \text {, terpilih } 31 \text { butir }\end{array}$ & 0,934 \\
\hline
\end{tabular}

\section{PENUTUP}

Pengujian validitas konstruk dengan menggunakan analisis faktor, pada uji coba pertama menggunakan metode eksploratori berhasil diekstraksi tujuh faktor sesuai dengan teori yang diestimasi. Faktor-faktor tersebut masing-masing adalah: (1) perencanaan perkuliahan, (2) pelaksanaan kegiatan pembe- lajaran, (3) penguasaan materi, (4) penguasaan strategi pembelajaan, (5) penguasaan metodelogi, (6) penguasaan pengelolaan kelas, (7) komunikasi, kedisiplinan, dan kemampuan evaluasi hasil belajar mahasiswa Meskipun ada faktor yang berbeda nama dengan yang diestimasikan, namun tetap bagian kajian teori. Ketujuh faktor tesebut 
diperoleh setelah dbuang sebanyak 31 butir, sehingga bersisa 40 butir pernyataan. Untuk uji coba kedua, menggunakan metode konfirmasi berhasil diperoleh tujuh faktor dengan membuang empat butir, sehingga diperoleh 36 butir pernyataan.

Penghitungan
reliabilitas yang dianalisis $\begin{array}{r}\text { koefisien } \\ \text { dengan }\end{array}$
menggunakan rumus alpha Cronbach,
didapat koefisien masing-masing sebesar
0,931 pada uji coba pertama, dan 0,934 pada
uji coba kedua.

\section{DAFTAR PUSTAKA}

Ancok, D. (2002). Teknik Penyusunan Skala Pengukur. Yogyakarta: Pusat Studi Kependudukan dan Kebijakan UGM.

As'ad, M. (1997). Psikologi Industri. Yogyakarta: Liberti.

Danim, S. (2003). Agenda Pembaruan Sistem Pendidikan. Yogyakarta: Pus-taka Pelajar.

Departemen Pendidikan Nasional. (2003). Kebijakan Departemen Pendidikan Nasional. Jakarta: Biro Hubungan Luar Negeri dan Humas.

Djamas, N. (2005). Strategi Pening-katan Mutu Dosen PTAI. Jakarta: Puslitbang Pendidikan Agama dan Keagamaan.

Hadi, S. (1986). Metodologi Research. Jilid 2. Yogyakarta: Yayasan Penerbit Fakultas Psikologi UGM.

Lase, J. (2003). Motivasi Berprestasi, Kecerdasan Emosional, Percaya Diri dan Kinerja. Jakarta: PPs FKIP UKI.

Mangkunegara, A. A., \& Anwar. (1975). Manaj-emen Sumber Daya Manusia Perusa-haan. Bandung: Remaja Rosda Karya
Miller, R. J. Developing Programs for Faculty Evaluation. San Fransisco: Jessey-Bass Publishers.

Mitchell, T. R. (1982). People in Organizations Understanding Their Behavior. New York: McGraw Hill, Book Company.

Prowirosentono, S. (1999). Kebijakan Kinerja Karyawan. Yogyakarta: BPFE.

Reddy, R. S. (1998). Principles and Practices of Teacher Education. New Delhi: Rajat Publication.

Schermerhorn, J. R. (1999). Management. New York: Willey \& Sons, Inc.

Soekartawi. (1995). Meningkatkan Rancangan Instruksional. Jakarta: PT Raja Gra-findo Persada.'

----------. (1995). Meningkatkan Efektivitas Mengajar. Jakarta: Pustaka Jaya.

Sudjana, N. (1995). Dasar-Dasar Proses Belajar Mengajar. Bandung: Sinar Baru Algesindo.

Departemen Pendidikan Nasional. (2001). Surat Keputusan Menteri Pendidikan Nasional Nomor 36/D/O/2001. Jakarta: Departemen Pendidikan Nasional.

Suryabrata, S. (2000). Metodolgi Penelitian. Jakarta: PT Raja Grafindo Persada.

---------. (2002). Pengembangan Alat Ukur Psikologis. Yogyakarta: Andi Offet.

(2004). Psikologi Pendidikan. Jakarta: PT. Raja Grafindo Persada. 
Jurnal Parameter Volume 29 No. 1

DOI : doi.org/10.21009/parameter.291.10

P-ISSN : 0216-26IX

Suyanto. (1988). Metode Statistika Multivariat. Jakarta: Departemen Pendidikan dan Kebudayaan.

Uno, H. B., Sofyan, H., \& Candiasa, I. M. (2001). Pengembangan Instrumen Untuk Penelitian. Jakarta: Delima Press.

Utomo, T., \& Ruijter, K. (1985). Peningkatan dan Pengembangn Pendidikan. Jakarta: PT. Gramedia.

Whitmore, J. (1997). Coaching For Performace: Seni Mangarahkan Untuk Mendongkrak Kinerja. Terjemahan oleh Y. Dwi Helly Purnomo. Jakarta: Gramedia Pustaka Utama. 